\title{
8. The Old and the Young in Early Medieval Iceland: The Evidence for Three-generational Families in the Household Cemeteries of Skagafjörður, Northern Iceland
}

\author{
GUĐNÝ ZOËGA
}

Zoëga, G. 2018. Across the Generations: The Old and the Young in Past Societies. AmS-Skrifter 26, 105-117, Stavanger. ISSN 0800-0816, ISBN 978-82-7760-181-6.

In recent years, a number of early Christian cemeteries have been excavated in the region of Skagafjörður, North Iceland. They belonged to, and were managed by, occupants of individual farms and were in use from around AD 1000-1120. These household cemeteries differ from the sparse pagan burial record in that they are 'all inclusive', i.e. they include individuals of both sexes and all ages, and essentially represent all inhabitants of a household. An interesting feature of the cemeteries is the large number of interred infants and relatively large number of 'older' individuals. By looking at the osteological data in conjunction with the placement of burials within cemeteries a more detailed picture of the Medieval household emerges, including the perception of the young and the aged and the possible role of three-generation families in the transference of knowledge and life experience. This paper discusses how this unique material can add to the predominantly philological and historical discussions on the nature, composition and social interactions of the Medieval Icelandic household.

Keywords: Medieval Iceland; households; Christianity; children; the old; generation

Address: Skagafjörður Heritage Museum, Glaumbær, 561 Varmahlíð, Iceland. Email: gudnyz@skagafjordur.is

\section{Introduction}

Iceland officially adopted Christianity around AD 1000 leading to profound cultural, political and societal changes in the following century. The eleventh century has, however, been a relatively poorly understood epoch in Icelandic history. In recent years archaeological excavations of early Christian cemeteries have provided a wealth of data on the Medieval households of eleventh-century Iceland. This paper builds on the results from two extensive archaeological projects, the Skagafjörður Church Project and the Skagafjörður Church and Settlement Survey (SCASS). Both projects have focused on settlement and church history in the region of Skagafjörður in Northern Iceland (Fig. 1).

To date, three early Christian cemeteries have been fully excavated in Skagafjörður, all of which were established around the time of the official adoption of Christianity in AD 1000. They were owned and managed by individual households which, over the course of 100-120 years, used them for the burial of their household members. The well-preserved skeletal collections from the cemeteries offer unique opportunities for the study of early Medieval society as all age groups and both sexes are represented, resulting in a near-complete representation of a household population. This is very different from the preceding pagan burial record, where women and children are underrepresented (Zoëga 2015, 120). Many of the household cemeteries ceased to be used in the late eleventh/early twelfth centuries, a situation that probably coincided with the establishment of more formal communal ${ }^{1}$ churchyards (Zoëga 2014, 35). The household-based cemeteries contain simple inhumations and lack grave goods or any ostentatious displays of wealth; nonetheless they contain rich osteological and burial data that can be used to infer internal household structures and social divisions. In this paper I want to give a short overview of how this research adds to our understanding of the Medieval Icelandic household, especially in relation to its oldest and youngest household members.

Perspectives that account for the human life course, the experience of ageing and the social perception of 
Figure 1: Map showing the location of the cemeteries at Keldudalur, Seyla and Keflavik in the region of Skagafjörður.

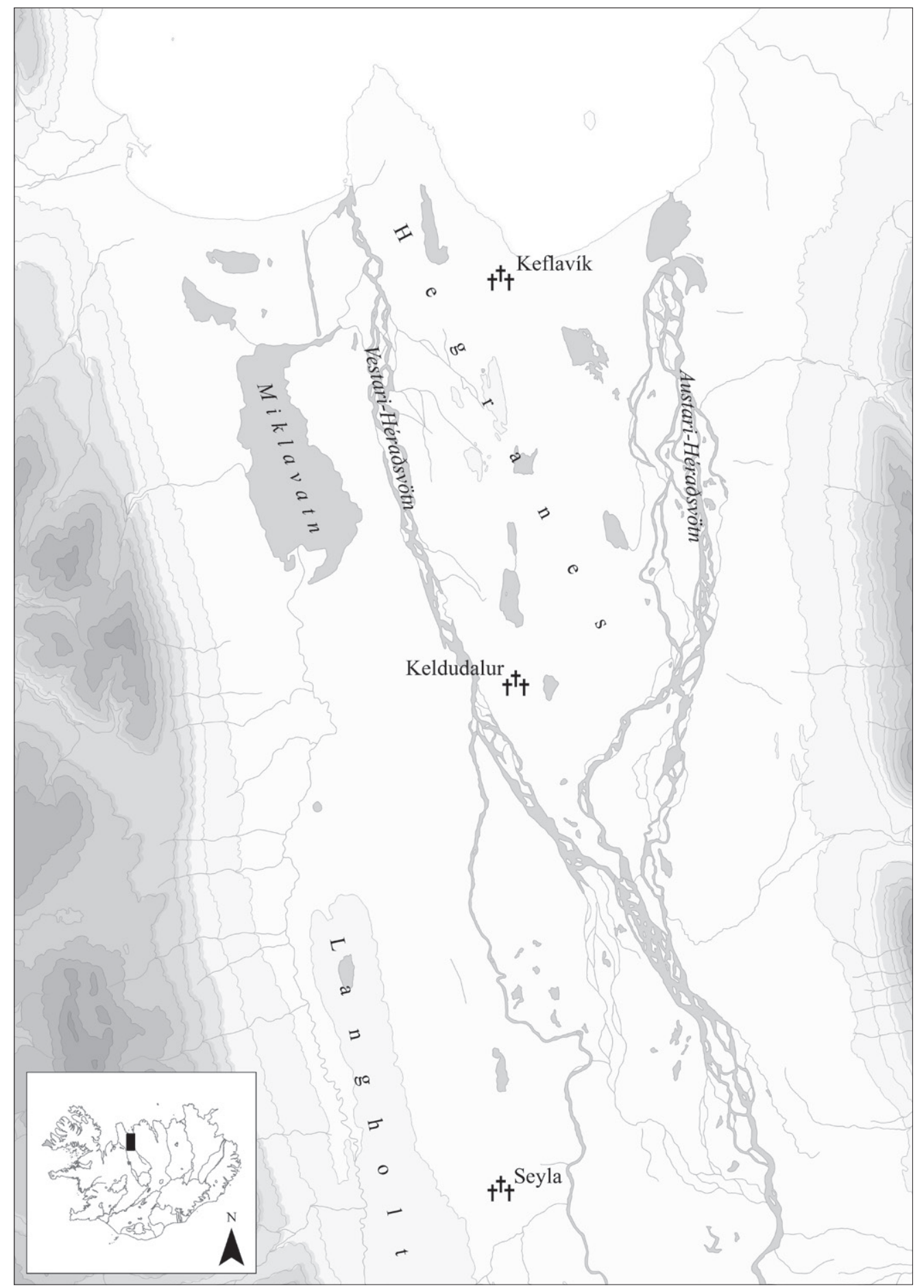

different life stages, are increasingly being incorporated into archaeological and bioarchaeological scholarship (see e.g. Gowland 2006; 2007; Sofaer 2006; Redfern 2007; Gilchrist 2012; Agarwal 2016). The social aspects and perception of old age has, as yet, received limited attention (but see Welinder 2001; Appleby 2010, Agarwal and Beauchesne 2011; Sofaer 2011), whereas the subject of children and childhood has been extensively researched (see e.g. Lillehammer 1989; Crawford 1999; Crawford and Shepherd 2007; Lewis 2007; Sellevold
2008, Halcrow and Tayles 2011; Murphy and Le Roy 2017). Neither life stage has received much attention in Icelandic archaeology, although new work by Gestsdóttir (2014) on osteoarthritis has touched on old age and disability, while an introductory paper by Callow (2006) explores avenues for the development of an archaeology of children. For the North Atlantic in general an edited volume, Youth and Age in the Medieval North, contains a number of relevant archaeological papers (Lewis-Simpson 2008). 
It is not my intention here to discuss the concepts of childhood or old age, but rather to examine how the osteological and burial data from the Skagafjörður cemeteries may enlighten us as to how these age groups were perceived and to what extent they may have interacted. The evidence for multigenerational families found in the cemeteries has significant implications for our understanding of the Medieval Icelandic household. Intergenerational transference of knowledge and shared life experiences would have enhanced and extended the shared social bond of the household, thereby facilitating household cohesion and a sense of familial identity. Such interaction would have depended on how common three-generational families, in which children and grandparents co-existed in the same household, might have been. It has been a widely held assumption that, due to a low average age of the general population, three-generational families were rare in Medieval times (Crawford 1999, 114; Sigurðsson 2008, 236; but see Chamberlain 2006, 56 for an opposing view). Based on analysis of the Skagafjörður cemetery populations, I argue that three-generational families, or at least three-generational households, were not uncommon.

\section{The Social Background}

Iceland was settled in the late ninth century by people, predominantly from Norway, but also from other Scandinavian countries as well as northern Britain. By the eleventh century the Skagafjörður region had become home to a substantial number of independent households occupying dispersed farmsteads. In Iceland there were no villages or central government although a common legislative structure was in place. The political and religious elite were the chieftains or goðar (singular: goði). Each goði headed a political entity called a goðorð. Farmers, and by association their households, were allied to these chieftains and, effectively, were under their protection (Hastrup 1985, 120-1; Sigurðsson 1999, 121; Karlsson 2004; 157). The lack of a centralised government meant that communal efforts, such as poor relief, were dealt with under the auspices of the 'hreppr', which were geographically defined areas usually consisting of at least twenty free farmers (Jóhannesson 1956, 103).

Essentially, individual farms and their households comprised the core units of society and were largely dependent on their own produce for economic survival. Roberta Gilchrist $(2012,114)$ has described early European households thus: 'In pre-industrial societies the household is the residential centre of both production and consumption; it is the focus of social relations and biological reproduction; and it accommodates dual domestic and ritual functions'. Similarly, the early Medieval Icelandic household was, mostly, a self-sufficient social and economic unit reliant on its own produce and the ability of its members to take part in the economic activities of the farm (Bolender 2007, 401).

\section{The Icelandic Medieval Household}

The definition of a household is not straightforward, and the form and function differs between regions and time periods. The three overarching types of households as defined by Laslett and colleagues (1972, 28-31) constituted the simple (nuclear family), extended (a conjugal unit and dependents) and multiple (two or more related conjugal units). These definitions have been elaborated upon by other scholars, but no consensus exists. The simple family household has been considered the predominant household type in pre-industrial Europe (Garðarsdóttir 2015, 6). In Iceland, where the farming household was universal, early Medieval households were nonetheless a fluid construction and existed in many shapes and sizes, ranging from a single individual to large complex households in which more than one family shared a dwelling.

According to Medieval laws a householder, if of sufficient means, was responsible for the upkeep of his parents, various relatives, his freed slaves and workers as well as his wife and children (Dennis et al. 2000, 29-30). Sigurðsson $(2008,238)$ has suggested this responsibility might not have been straightforward as the kinship system was bilateral, which meant that each individual had an extensive background of relatives for which they were responsible. In fact, 'friendships' and social ties might have meant more than kinship alone (Sigurðsson 2008, 238). A household might, therefore, have harboured a selection of related and unrelated individuals, many of whom may have had short-term associations with specific households (Miller 1990, 114; Sigurðsson 2008, 232). Miller $(1988,322)$ has defined the Icelandic household broadly: 'I thus consider, contrary to the Cambridge typology, that a farmstead run as a unified economic enterprise can constitute a single household even if some of its members are not related or do not recite kinship as the reason they are housed together'. Icelandic farm properties sometimes included dependent sub farms. I have extended the household definition to include all members of a single farm property 
irrespective of whether they shared a house. Therefore, the 'household' cemetery might encompass individuals from farms, with more than one dwelling, or occupants of dependent crofts and rented farmsteads. Perhaps that definition best fits the term familia, which was used from Roman times and throughout the Medieval period to describe the occupants of a house or houses, including the core family, servants, slaves or other individuals (Herlihy 1991, 9).

\section{The Written Sources}

The application of multiple avenues of research is essential to the interpretation of Medieval households and it is important to employ as many different avenues of research as possible. Archaeology has contributed significantly to the understanding of Icelandic burial customs, settlement structure, house form and economic activity, but discussions on households and social structure have primarily relied on the work of philologists and historians working on Medieval Icelandic vernacular literature and laws. Medieval Icelandic written sources may roughly be divided into four categories - Icelandic family sagas, sagas dealing with the settlement period and Christianisation, contemporary sagas, and normative sources including the early law codes, church cartularies, property deeds and other Medieval documentation. The family sagas deal partly with the period when the cemeteries were in use and offer a fascinating insight into early Icelandic society. They were written centuries after the events they purport to describe, however, and their historicity has been questioned (Miller 1990, 44; Sigurðsson 2008, 228).

Whatever their perceived historicity, the sagas create a basis for understanding the general nature and makeup of Icelandic Viking Age Medieval society. In the words of Sigurðsson (1999, 28):

We are unlikely to be able to answer the question of whether the descriptions of people and events in the Sagas of Icelanders are factual or fictional, but we can agree on the picture they give of society. The picture the sagas give of society is not dependent on the historicity of the individual narratives. Fictional conversations or characters do not automatically imply that the feuds, motifs, norms, gift exchange or social structure of these sagas are invented.

By employing careful source criticism, the depiction of society found in the sagas may add to, and be enhanced by, osteological discussions of, for instance, age, gender, social inequalities and disability as well as attitudes towards particular social groups such as children and the old. It must be stressed that no contemporary written sources exist for the period under discussion, however, and most of the saga material deals with society prior to the Christian eleventh century, while the law codes and contemporary sources postdate it. The Skagafjörður cemeteries, therefore, add a primary source of information on the household of the early Christian era that is largely absent from any of the other sources.

\section{The Old and the Young in the Written Sources}

The responsibility of the householder toward his charges included their upkeep even if disabled, frail or for some reason unproductive, including the very young and the very old. These individuals are largely missing from the written records, however, which mostly describe the social realities of the elite and powerful. They focus on the actions of the younger and middleaged adult groups which is perhaps not surprising as they were the most active and conspicuous demographic groups, managing farms, rearing children and getting embroiled in noteworthy conflicts.

Medieval literature, both European and Icelandic, points to childhood being perceived as a distinct life stage (Hanawalt 1993, 456-7; Arnórsdóttir 2005, 101). We have little knowledge of whether there were different stages of childhood, however, and when, effectively, childhood ended. Contemporary studies indicate that at five years of age children start being socially aware and are able to undertake simple household chores (Lewis 2007, 6-7) which, even if not signalling adulthood, indicates the start of a child's role as a productive household member. The earliest Christian section of the Icelandic Medieval laws made allowance for a boy of seven years to perform emergency baptism if an adult male was not available to undertake the task (Karlsson et al. 1992, 4). Women were only allowed to perform emergency baptism if no males, seven years or older, were available but the law does not stipulate a minimum age for women. This suggests a possible shift in the social status of children, at least male children, taking place around the age of seven years. According to the legal texts the advent of adulthood happened at 12-16 years, but perceived adulthood may have depended upon the maturity of the individual rather than a particular age (Pórarinsdóttir 2005, 117; Sigurðsson 2008, 230). Written sources also indicate that 


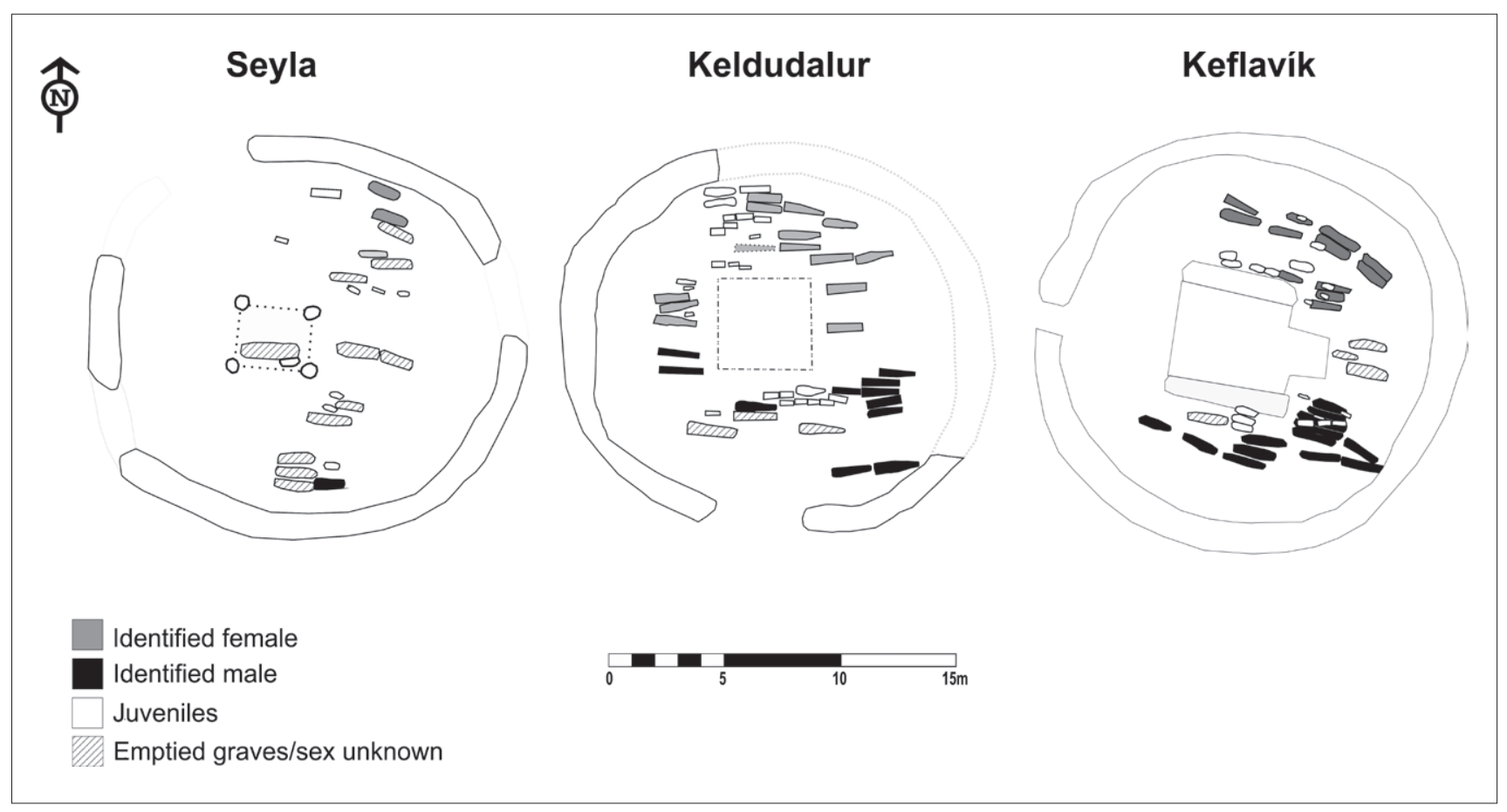

Figure 2: Diagram showing the sex segregation at the three cemeteries. Women were buried in the northern half, while men were interred in the southern half. Juveniles, under the age of 18 years, were relatively uniformly distributed between the male and female sides, indicating they might also have been buried according to their biological sex.

marriage was not uncommon for individuals under the age of twenty years (Miller 1988, 333).

Senescence is more difficult to define as the cultural perception of old age depended more on the physical and social functionality of an individual rather than their chronological age (Sigurðsson 2008, 231; Sofaer 2011, 287). The sagas do tell of individuals who maintained their power and function into chronological old age (Jakobsson 2008, 266) but, in general, they paint a negative picture of those who were considered elderly. Such individuals tend to have negative associations in terms of their appearance and decreased power and social importance (Jakobsson 2005, 325; Sigurðsson 2008, 234-5).

\section{The Burial Data}

The early Christian household cemeteries are invaluable sources for the examination of the demographic makeup, living conditions, health and diet of Medieval household populations. They are demographically limited in that they do not represent the larger community. The opportunities for social analyses offered by, the often deceptively simple, early Christian cemeteries are increasingly being recognised.

The skeletal and burial data presented here is derived from three fully excavated early Christian cemeteries, Keldudalur, Seyla and Keflavík (see Fig. 1). Excavations at Keflavík have just been completed and the data presented here is, therefore more preliminary than that from the other two sites. All three cemeteries are located in lowland Skagafjörur and each comes with its own sets of possibilities and restrictions: Keldudalur and Keflavík have both produced relatively complete skeletal assemblages (sixty-two individuals at Keldudalur and fifty at Keflavík) but only that of Keldudalur has been fully analysed. The Keldudalur site was discovered through construction work and nine graves, as well as the church architecture and any possible grave markers, had been damaged before rescue excavations began. The Keflavík cemetery was discovered, but also partly disturbed, when an electricity line was laid through the area. However, the damage was limited to a small number of graves and the site included a well-preserved skeletal sample, cemetery architecture, and exciting new data on various burial customs. The cemetery at Seyla was not damaged by modern construction work but it had been subject to large scale excavation and the emptying of graves in the middle of the eleventh century when the entire farm and cemetery were relocated about $50 \mathrm{~m}$ uphill. It contained twenty-five graves, half of which had been emptied. Although the site only provided a handful of intact skeletons, it offered a unique view of cemetery closure and the selective removal of burials, which added to the social interpretation of the material (Zoëga and Bolender 2017, 84). 
All three cemeteries showed a marked degree of structural similarity: they were circular in shape, about $17 \mathrm{~m}$ across, with a small central church and burials predominantly located to the north, east and south. The interments were simple inhumations, orientated west-east, with the head to the west. Many graves contained coffins but no grave-goods or elaborate furnishings. An important factor for the interpretation of the material is the fact that the graves formed a single burial layer and intercutting was rare, allowing for a more complete skeletal assemblage and evidence of original burial layout. In the absence of grave goods, various burial traits may be used as social markers including the presence/absence of coffins, the location and layout of the graves as well as the positions of bodies within them. Osteological analysis offers data for assessing the social components of these cemeteries through the study of age, sex, stature and pathology. These varying components of the burial environment may be used to detect differences in burial treatment according to age, sex or social status (Jonsson 2009, 37-42).

Social segregation based on status and sex, or zoning of cemeteries, is prescribed in the earliest Christian section of the twelfth-century Norwegian provincial laws (Fig. 2). Church owners and higher status individuals were to be placed next to the church and those of lowest standing should be buried next to the cemetery wall. Cemeteries were also sex segregated with women buried to the north and men to the south (Halvorsen and Rindal 2008). Similar sex segregation has been observed to varying degrees in early Christian cemeteries in Iceland, Scandinavia and the North Atlantic (Steffensen 1943, 231; Gejvall 1960, 124, Cinthio 1988, 125; Kieffer-Olsen 1993, 121; Lynnerup 1998, 61-2; Jonsson 2009, 91-3). Interestingly, although segregation by sex is clearly evident in the Icelandic cemeteries, this is not mentioned in the Medieval Icelandic laws

Different forms of social zoning have been detected in all three cemeteries. The most notable are the clustering of children's graves, differential use of coffins according to the location of graves within cemeteries, as well as a complete segregation of the sexes (see Fig. 2). Children's skeletons cannot be accurately sexed, except by aDNA analysis, which has not been conducted on the material. To what extent sex segregation extended to children, therefore, cannot be established with certainty but, in all cemeteries, roughly equal numbers of children appear to have been buried in the male and female sections of the cemeteries. This finding may suggest that children were assigned similar identities, on the basis of sex, to adults.
Coffin graves were frequent at all three sites, but graves without coffins tended to be found in the outer areas of the cemeteries and may be indicative of the different social standing of the individuals interred there (Fig. 3). Graves without coffins also tended to occur in clusters, suggesting that those individuals might have been related, perhaps families of freed slaves or belonged to a subsidiary household, perhaps from rental farms or crofts or slaves or workers of the farm.

The remarkable grave emptying episode witnessed at Seyla demonstrated that certain social segregation was exercised in the selective removal of burials at the closure of the cemetery as well as during its period of use (Zoëga and Bolender 2017, 83-5). Adults interred by the cemetery walls were left behind as were most of the children, irrespective of where they were placed (see Fig. 2). This reinforces the idea that burials by the cemetery walls were afforded to those of lower personal standing, although the lack of emphasis on emptying children's graves is curious. The twelfth-century Icelandic Medieval law book Grágás emphasises that baptism was a prerequisite for burial in a Christian burial ground (Karlsson et al. 1992, 1-5). Many infants at Keldudalur had died at, or soon after, birth and may have been buried without being baptised. A substantial number had been afforded coffins and were placed in the most coveted location next to the church. The data therefore seems to indicate that children were assigned a similar status as adults in burial, at least in terms of inclusion and placement within the gendered zones of the cemetery. That children were deliberately left behind when the cemetery at Seyla was relocated seems to be evidence to the contrary, however, although this unique event may not be representative of the general attitude that was held towards children.

Removal of bodies from individual graves, clusters of graves or even whole cemeteries, has been observed at numerous early Medieval sites in Europe (see e.g. Klevnäs 2013; Crangle 2015). Removal of bodies from Medieval cemeteries has, for instance, been associated with the encroachment of urban settlements and burial overcrowding once cemeteries became bounded in the tenth to eleventh centuries (Cherryson 2007, 137-8; Hadley 2007, 200). The law book Grágás contains a detailed section on bone removal from decommissioned cemeteries, emphasising in great detail how each bone was to be carefully removed (Karlsson et al. 1992, 10). This law was, most likely, meant to counteract the apparently casual and selective removal episodes witnessed, for instance, in the Skagafjörður cemeteries (three individuals from Keldudalur, four from Keflavík 


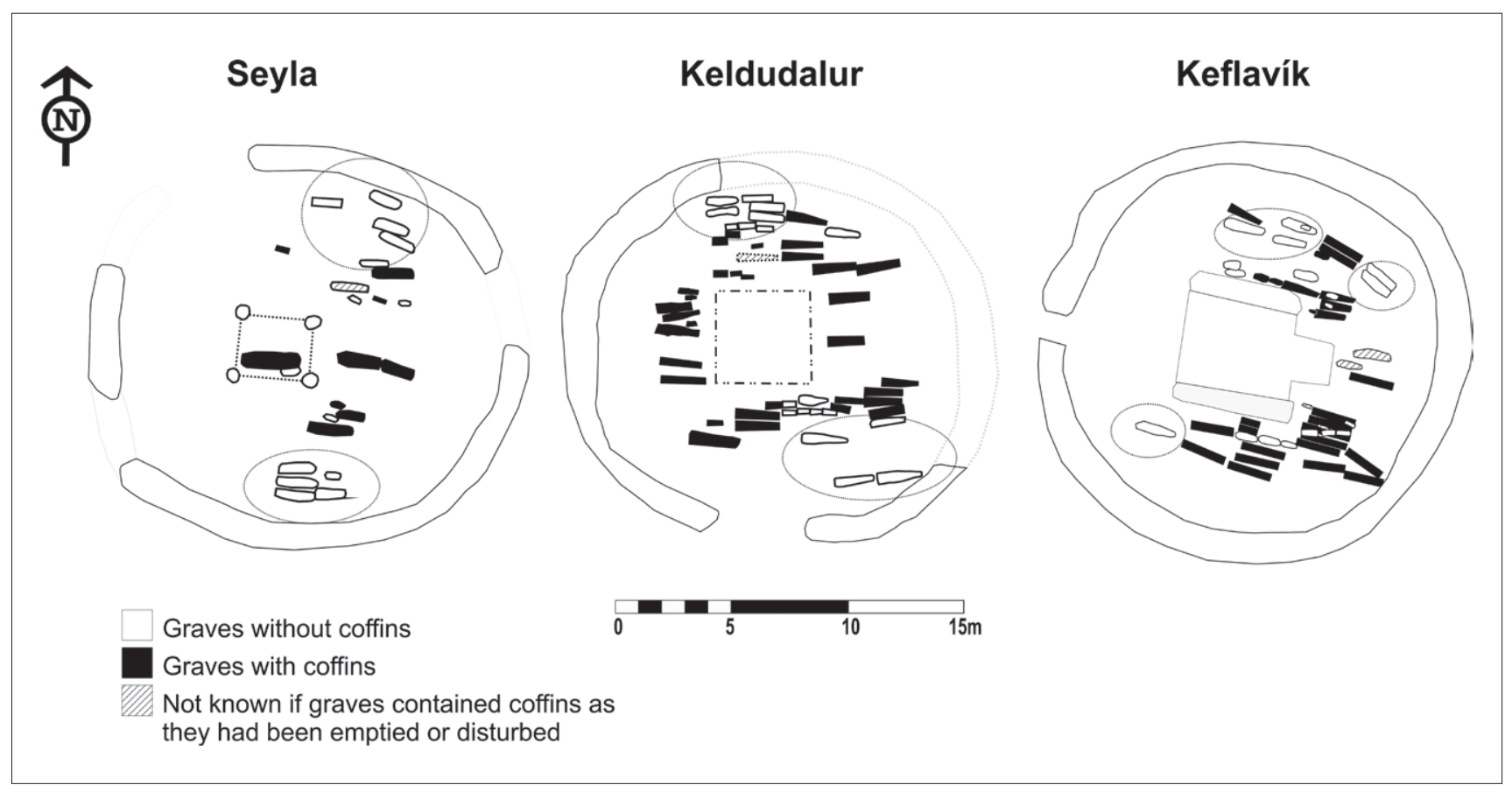

Figure 3: Comparative diagram showing coffin graves in the three Skagafïrður cemeteries. Graves of adults without coffins are circled. At Seyla and Keflavik there were remnants of coffins in some graves that had been emptied, probably because the coffins had started to deteriorate. In three graves near the church the presence of coffins could not be determined perhaps because they had been complete enough to be removed in their entirety. At Keldudalur and Seyla, the graves of adults without coffins were clustered by the cemetery walls. The situation was slightly different at Keflavik where only one male, but five females had not been interred in coffins.

and twelve from Seyla). These removals speak of the individualistic actions of families managing their own cemeteries, perhaps a continued practice of an earlier pagan tradition of household control over mortuary activities. For some reason it was deemed appropriate that select individuals were relocated to a newly assigned communal cemetery or, in the case of Seyla, a new cemetery on the same farm. Relocated individuals might have been immediate members of the resident family at the time of cemetery closure or perhaps the cemetery founders or family ancestors.

\section{The Skeletal Data}

The osteological analysis indicates that roughly equal numbers of men and women were interred in the cemeteries; if we accept the burial data is suggestive of the segregation of children by sex then there appears to have been also generally equal numbers of boys and girls. These trends are indicative of populations that were relatively stable and homogenous.

Figure 4 provides details of the age categories assigned to the Keldudalur population. It must be cautioned that the skeletal assemblage of sixty-two individuals is too small for extensive statistical work and because of the small sample size, the skeletons that could not be assigned an age with any certainty, might skew the

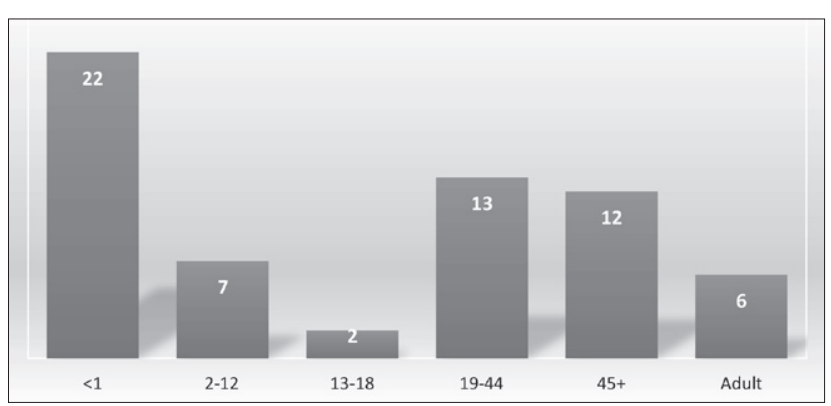

Figure 4: Bar chart showing the age categories at the Keldudalur cemetery. The largest category is that of infants under 1 year of age (35\%; 22/62). By comparison, there are relatively few skeletons of older children (11\%;7/62). There are only two skeletons in the subadult category (13-18 years). Adults from ages 19-44 years comprise about 20\% (13/62), while older individuals (45+years) also constitute $20 \%$ (12/62). The adult category comprises individuals over 18 years of age, but where age could not be defined more accurately.

numbers considerably. Nevertheless, the high mortality rate for infants under one year of age is notable (35\%; $22 / 62)$, while $47 \%(29 / 62)$ of children had died at less than twelve years of age. A further interesting observation is the relatively high number of adults placed in the 'old adult' or $45+$ years category, about $20 \%(12 / 62)$ of the entire collection, but $38 \%$ of all adults (12/32).

When the complete skeletal assemblage at Keldudalur is considered, the average life expectancy only came to about twenty years which may seem abnormally low. 
Similar numbers, however, have been recorded in rural Medieval cemeteries in Norway (Benedictow 1993, 39). In general, once past the first-year mark, life expectancy appears to have been relatively good and, when only adults are considered, the average age amounts to approximately forty years, which is similar to that of many Medieval populations (Sellevold 2001, 125; Hamre 2011, 193).

Ageing is a multifaceted concept that may be divided into three distinct components. The first is chronological age, i.e. the estimated time from birth to death. The second is social age which is defined by physical appearance and behaviours that are culturally perceived as defining a particular age group. The third is physiological age, which encompasses medical and physiological factors that affect an individual's functional abilities and societal participation (Gowland 2006, 144-5; Sofaer 2011, 290-1). Here I have divided the sample into age categories that may, to some extent, be representative of different life stages as they would have manifested in Medieval Iceland (see Fig. 4). Those under one year of age are termed infants and are put in a special category as the death rate falls steeply past the one-year mark. The category of children ranges from 2-12 years of age, with twelve years being the lower social threshold in the laws for adulthood. The juvenile category extends from 13-18 years as, sometime during those years, people officially entered adulthood (Pórarinsdóttir 2005, 117). The adult category (19-44 years) extends over the period when people would have been actively managing farms and raising a family. Older individuals placed in the $45+$ years category, might not have been perceived as elderly, but had lived past the estimated average age of forty years for adults and, if they had produced children, were likely to have become grandparents. Estimating old age is fraught with difficulties as the osteological methods of age evaluation rely on skeletal degeneration, which may differ greatly between individuals, areas and populations (see Appleby 2011; Cave and Oxenham 2016). Historically, old age was considered to start at sixty years (Shahar 1997). In the Keldudalur population, four individuals had an upper age limit of 55-60 years and could very well have lived past the sixty-year mark.

The high rate of infant death seems to indicate that some underlying environmental or socio-economic factors were affecting their survival but it must be considered that the infant death rate in pre-industrial societies may have exceeded $30 \%$ (Lewis 2007, 82). In later centuries, Iceland suffered the highest levels of infant death of the Nordic nations (up to 600 deaths per 1000 births), partly due to the practice of artificially feeding infants (Garðarsdóttir 2002, 23, 221-2; Guttormsson and Garðarsdóttir 2002, 163-4). In preindustrial Europe, weaning often occurred around two years of age (Lewis 2007, 86) but early weaning might, to some extent, explain the high death rate of infants less than one year old. To what extent artificial feeding was practiced in Medieval Iceland is not known, but feeding and hygiene practices, as well as periodic or seasonal food shortages would all have contributed to the lack of infant survival.

Skeletal pathology, indicative of age and activity related degenerative changes, were common in the Keldudalur sample. An overall high rate of degenerative joint disease was evident although it was by far most prevalent in the old adult category where ankylosing or fusing of joints and vertebral bodies was common (Zoëga and Murphy 2016, 580). This would have affected gait and movement in general. Dental calculus, infections, abscesses and tooth loss were also prevalent, again with the highest rates occurring in the old adult categories, with all such individuals having lost one or multiple teeth. Skeletal changes that may seem severe do not always reflect the level of pain and incapacitation an individual experienced. Restricted movement as well as the facial and speech changes caused by loss of teeth and severe calculus, however, might have given individuals the appearance and gait of old age, even when young by modern standards. Other problems associated with ageing, such as loss of eyesight or hearing or dementia are, of course, not visible in the bones and cannot be evaluated but these traits have been noted in the Sagas as markers of old age (Sigurðsson 2008, 232).

\section{The Young and the Old in the Cemetery}

The number of well-preserved infant skeletons retrieved from the Keldudalur cemetery added a new dimension to the discussion of Medieval demography and burial customs. Prior to the excavations, no early Christian cemetery with good bone preservation had been completely excavated in Iceland and little was known about the living conditions and burial customs afforded to children. In the preceding pagan burial record, infants and children are conspicuously missing, either because of preservational factors, cultural reasons, or both. A similar scarcity of children has been noted in contemporary burial material in Scandinavia and Britain (Sellevold 1997, 15; Lee 2008, 19; Friðriksson 2009, 18). 


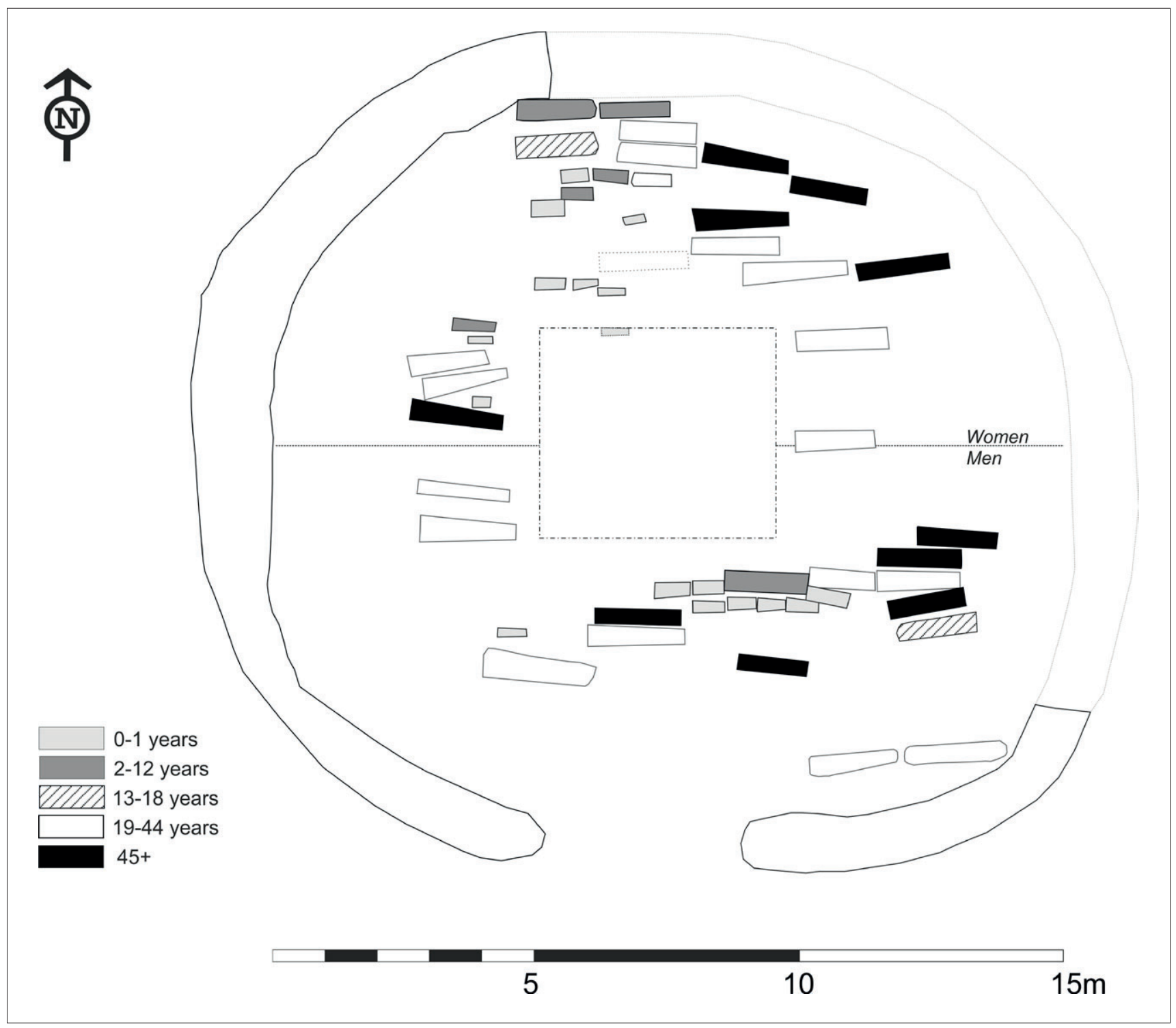

Figure 5: Diagram showing the locations of the old and the young within the Keldudalur cemetery. Infants younger than one year of age were buried closer to the church, especially on the male side. Older children were less likely to be interred in coffins and none of the three individuals aged 7-12 years had coffins. No differentiation was found in the locations of old adults, aged 45 years and older.

The special treatment of infants has been widely reported for early Christian cemeteries (e.g. Lee 2008, 36; Mejsholm 2009, 238-9; Craig-Atkins 2014, 103) and some of these practices are echoed in the Skagaförður material. The children were often buried in rows or clusters, sometimes right next to the church. There are indications that in the earliest cemetery phases, however, children were buried next to adult graves or, as in a number of cases in Keflavík, within the grave-fill of adult graves. The appearance of rows and clusters may therefore, at least partly, be an eleventh-century developmental feature (Fig. 5). The Keldudalur material suggests that children were buried in different areas according to age. In general, infants under one year of age were buried closer to the church, while older children and juveniles seem to have been buried further away. At the Medieval rural cemetery of Raunds, Northamptonshire, England, infants under one year of age were similarly buried next to the church walls (Craig-Atkins 2014, 97). Different burial locations for various age categories of children have been noted in some Scandinavian cemeteries and have, tentatively, been associated with the roles and function of the particular age groups (Jonsson 2009, 62-3). Another indication of differential treatment at Keldudalur was the lack of coffins in the graves of older children, whereas most infants under one year of age were interred in coffins.

The evidence for the treatment of children in the Skagafjörður burial record is somewhat contradictory. The placement of infants next to, or close by, the church, as 
well as the frequent burial of infants in coffins, can be interpreted as a symbol of, if not special status, at least their full inclusion in the household and the Christian community. At the same time, the selective abandonment of children of all ages in the graves at Seyla, seems to indicate disinterest in their fate in the afterlife.

As yet, there is little to indicate that older individuals were subject to differential burial treatment in any of the Skagafjörður cemeteries. All but two of the 45+ years individuals at Keldudalur were interred in a coffin and their graves were dispersed throughout the cemetery (see Fig. 5). No discernible differences in the burial treatment of individuals with extensive pathological changes, neither young nor old, were apparent. The same has also been noted for early Icelandic cemeteries at Hofstaðir and Skeljastaðir (Gestsdóttir 2014, 158) as well as in Norwegian material (Hamre 2011, 211).

\section{Discussion}

The all-inclusive nature of the early Christian household cemeteries is a departure from earlier, highly selective, burial practices and highlights the importance of the household as a social unit. It is impossible to estimate how many of the original farm population may be missing from the burial record. The relatively equal numbers of men and women and the presence of all age groups, however, may be indicators that the cemetery groups are representative of the farm populations during the period of cemetery use. The size of an average household in Medieval Iceland has been estimated as ranging anywhere from six to twenty individuals based on various historical estimations (Steffensen 1975, 49; Arnórsdóttir and Porláksson 1998, 48; Sigurðsson 2000, 47). In the first country wide census from AD 1703, the average household was estimated to be around 5.5 to 7.5 individuals (Sigurðsson 2000, 47; Hanjal 2005, 35). The osteological data from the Skagafjörður cemeteries suggest that living populations at all three farmsteads might have included, on average, eight to ten individuals, possibly five to seven adults and one to four children. Since older adults could have constituted about $40 \%$ of the adult population, there might have been one to three older individuals per household.

The 1703 census is an important population-appropriate source of data on early Icelandic households. It is unique in that it details the names, ages and social positions of each household member. The census was collected in the early eighteenth century at the end of a long spell of hardship that had caused widespread famine and increased death rate (Guttormsson and
Garðarsdóttir 2005, 85-6). It is, therefore, not to be expected that the census is indicative of the realities of the eleventh century. Nonetheless, it provides an important reference as it depicts the demography and social situation of pre-industrial rural Icelandic households. As such, it has been used for the historical reconstruction of Medieval Icelandic society (see e.g. Sigurðsson 2000, 47; 2008, 236).

It has been argued that the scarcity of three-generational families in the 1703 census (12\%) is suggestive they would probably also have been rare during Medieval times (Sigurðsson 2008, 236). It must be considered, however, that the lack of older individuals within the adult population in the census may be a reflection of the preceding periods of hardship rather than being representative of an expected age structure.

So, what can the osteological and burial data from the Skagafjörður cemeteries tell us about possible interactions between the old and the young in Medieval Iceland? Given that some people appear to have reached a high age, the cumulative lifespans of individuals in the Keldudalur cemetery might have extended from the middle of the tenth century until the early twelfth century, possibly up to a period of 150 years. This encompasses the settlement period, pagan times, and the extensive social changes associated with Christianisation and ecclesiastical institutionalisation.

This extended period should not just be divided into epochs of separated households or families but also seen as an aggregation of interconnected generations. A generation has been defined as a social unit with individuals of different origin and ages that share, at least partly, the same life experiences (Sayer 2010, 65; Gilchrist 2012, 17-19). A generation is generally estimated to be the length of time from a mother's first child to her daughter's first child. The age of marriage for women in Iceland may have been low (Miller 1988, 333). This is reflected in the inheritance section of the Medieval laws which state that a married, or indeed widowed, woman, sixteen years or younger may claim inheritance (Dennis et al. 2000, 8). In that case, younger parents could have made young grandparents, thereby increasing the probability of three-generational families. I have elsewhere suggested that for the Keldudalur household a generation of 20-25 years may be reasonable, assuming that early marriage was common and women had children at a young age (Zoëga 2015, 111). Generation length is here calculated to be the time between a mother's first child and her daughter's first child. The Keldudalur assemblage would then include four to five generations, allowing for one to three older 
individuals per generation. The analysis of the skeletons from the neighbouring Keflavík cemetery is in its early stages but seems to suggest a demographic profile akin to that of the Keldudalur population. This supports the notion that Keldudalur was not an anomaly and that three-generational families or households might have been commonplace at this time.

\section{Conclusions}

We have only just started assigning social interpretation to the early Christian cemeteries in Iceland but the old and the young are emerging as meaningful social entities. It has been assumed that, due to the low life expectancy of the population, three-generational families would have been rare in Medieval Iceland and Europe. As shown here, older adults (45+ years) would have constituted almost half of the adult population. Able bodied individuals over the age of forty-five years need not have been considered socially old, but if they had born children that survived, they would likely have assumed the role of grandparents, either to children within or outside the household. Although the comparative demographic and palaeopathological reconstructions of these cemetery populations are still in their early stages, I hope I have managed to show that three-generational families or households need not have been a rarity in early Medieval Iceland. It seems highly probable that many children would have known and interacted with their grandparents or other 'elderly' people on a daily basis.

\section{Acknowledgements}

This work was made possible by various grants from the Icelandic Archaeology Fund and the US National Science Foundation (BCS \# 0731371, PLR \# 1242829 and 1345066). The analysis presented here is based on various collaborative projects and I want to thank all of the specialists and students that have contributed. Special thanks go out to Kimmarie Murphy for her contribution to the osteological analyses. I also wish to thank Kathryn Catlin and Douglas Bolender for their useful comments on an earlier draft of the paper. I am also grateful to Bryndís Zoëga for preparing the site map.

\footnotetext{
Note

${ }^{1}$ Here, the term communal is used for cemeteries which integrate a community of multiple households from multiple farms.
}

\section{References}

Agarwal, S. C. 2016. Bone morphologies and histories: life course approaches in bioarchaeology. Yearbook of Physical Anthropology 159, 130-49.

Agarwal, S. C. and Beauchesne, P. 2011. It is not carved in bone. Development and plasticity of the aged skeleton, pp. 312-33 in Agarwal. S. C. and Glengross, B. A. (eds.), Social Bioarchaeology. Chichester: Wiley-Blackwell.

Appleby, J. E. P. 2010. Why we need an archaeology of old age, and a suggested approach. Norwegian Archaeological Review 43, 145-68.

Appleby, J. E. P. 2011. Bodies, burials and ageing: accessing the temporality of old age in prehistoric societies. Oxford Journal of Archaeology 30, 231-46.

Arnórsdóttir, A. S. 2005. Nokkrar hugleiðingar um kynbundið uppeldi á miðöldum, pp. 101-12 in Jakobsson, Á. and Tulinius, T. H. (eds.), Miðaldabörn. Reykjavík: Hugvísindastofnun Háskóla Íslands.

Arnórsdóttir, A. S. and Porláksson, H. 1998. Heimili, pp. 57-69 in Guðmundsson, G. J. and Björnsson E. K. (eds.), Íslenska sögupingið. Ráðstefnurit I. Reykjavík: Sagnfræðistofnun Háskóla Îslands. Sagnfræðingafélag Íslands.

Benedictow, O. J. 1993. The Medieval Demographic System of the Nordic Countries. Oslo: Middelalderforlaget.

Bolender, D. J. 2007. House, land, and labor in a frontier landscape: the Norse colonization of Iceland, pp. 400-21, in Beck, R. A (ed.), The Durable House: Architecture, Ancestors, and Origins. Carbondale: Center for Archaeological Investigations, Southern Illinois University.

Callow, C. 2006. First steps towards the archaeology of children in Iceland. Archaeologia Islandica 5, 55-96.

Cave, C. and Oxenham, M. 2016. Identification of the archaeological 'invisible elderly': an approach illustrated with an Anglo-Saxon example. International Journal of Osteoarchaeology 26, 163-75.

Chamberlain, A. 2006. Demography in Archaeology. Cambridge: Cambridge University Press.

Cherryson, A. K. 2007. Disturbing the dead: urbanisation, the church and the post-burial treatment of human remains in early medieval Wessex, c. 600-1100, pp. 130-42 in Semple, S. (ed.), Early Medieval Mortuary Practices. Oxford: Oxford University School of Archaeology.

Cinthio, H. 1988. En kyrkogård från 1000-talet i Löddeköpinge, pp. 121-6 in Iregren, E., Larsson, L. and Jennbert, K. (eds.), Gravskick och gravdata: rapport från arkeologidagarna 13-15 Januari 1988. Lund: Institute of Archaeology, University of Lund.

Clover, C. J. 1988. The politics of scarcity: notes on the sex ratio in early Scandinavia. Scandinavian Studies 60, 147-88.

Craig-Atkins, E. 2014. Eavesdropping on short lives: eaves-drip burial and the differential treatment of children one year of age and under in the early Cristian cemeteries, pp. 95-113 in

Hadley, D. M. and Hemer, K. A. (eds.), Medieval Childhood: Archaeological Approaches (SSCIP Monograph 3). Oxford: Oxbow Books.

Crangle, J. 2015. A Study of Post-Depositional Funerary Practices in Medieval England. Unpublished PhD thesis, University of Sheffield.

Crawford, S. 1999. Childhood in Anglo-Saxon England. Stroud: Sutton.

Crawford, S. and Shepherd, G. (eds.) 2007. Children, Childhood 
and Society. IAA Interdisciplinary Series Vol. I: Studies in Archaeology, History, Literature and Art (BAR International Series 1969). Oxford: Archaeopress.

Dennis, A., Foote, P. and Perkins, R. 2000. Laws of Early Iceland. Grágás II. Manitoba: The University of Manitoba Press.

Friðriksson, A. 2009. Social and symbolic landscapes in Late Iron Age Iceland. Archaeologia Islandica 7, 9-21.

Garðarsdóttir, Ó. 2002. Saving the Child: Regional, Cultural and Social Aspects of the Infant Mortality Decline in Iceland, 17701920. Unpublished $\mathrm{PhD}$ thesis, Umeå University.

Garðarsdóttir, Ó. 2015. Residence patterns of the elderly in early eighteenth-century Iceland. The History of the Family 21, 5-20.

Gejvall, N. G. 1960. Westerhus: Medieval Population and Church in the Light of Skeletal Remains. Lund: Kungl. Vitterhets Historie och Antikvitets Akademien.

Gestsdóttir, H. 2014. Osteoarthritis in Iceland. An Archaeological Study. Unpublished PhD thesis, University of Iceland.

Gilchrist, R. 2012. Medieval Life. Archaeology and the Life Course. Woodbridge: Boydell Press.

Gowland, R. L. 2006. Ageing the past: age identity from funerary evidence, pp. 143-54 in Gowland, R. L. and Knüsel, C. J. (eds.), Social Archaeology of Funerary Remains. Oxford: Oxbow Books.

Gowland, R. 2007. Age, ageism and osteological bias: the evidence from Late Roman Britain. Journal of Roman Archaeology Supplementary Series 65, 153-69.

Guttormsson, L. 1983. Bernska, ungdómur og uppeldi á einveldisöld. Tilraun til félagslegrar og lýðfrceðilegrar greiningar. Reykjavík: Sagnfræðistofnun Háskóla Íslands.

Guttormsson, L. and Garðarsdóttir, Ó. 2002. The Development of infant mortality in Iceland 1814-1878. Hygiea Internationalis. An Interdisciplinary Journal for the History of Public Health 3, 151-77.

Guttormsson, L. and Garðarsdóttir, Ó. 2005. Purfamenn í manntalinu 1703, pp. 85-121 in Garðarsdóttir, Ó. and Guðmundsson, E. G. (eds.), Manntalið 1703. Prjú hundruð ára. Greinar i tilefni afmcelis. Reykjavík: Hagstofa Íslandspjóðskjalasafn Îslands.

Hadley, D. M. 2007. The garden gives up its secrets: the developing relationship between rural settlements and cemeteries, c. 750-1100, pp. 194-203, in Semple, S. (ed.), Early Medieval Mortuary Practices. Oxford: Oxford University School of Archaeology.

Halcrow, S. E. and Tayles, N. 2011. The bioarchaeological investigation of children and childhood, pp. 333-60 in Agarwal, S. C. and Glencross, B. (eds.), Social Bioarchaeology. Chichester: Wiley Blackwell.

Halvorsen, E. F. and Rindal, M. 2008. De eldste Østlandske kristenrettene (Norrøne tekster nr. 7.). Oslo: Riksarkivet.

Hamre, S. 2011. Burial Practices in Early Christian Norway. An Osteoarchaeological Study into Differences and Similarities Between Four Burial Assemblages. Unpublished PhD thesis, The University of Bergen.

Hanawalt, B. A. 1993. Growing Up in Medieval London: The Experience of Childhood in History. New York: Oxford University Press.

Hanjal, J. 2005. The Icelandic census of 1703 in perspective, pp. 31-8 in Guðmundur, E. and Garðarsdóttir, Ó. (eds.), Manntalið 1703 prjú hundruð ára. Greinar í tilefni afmelis. Reykjavík: Hagstofa Îslands-Pjóðskjalasafn Î́slands.

Hastrup, K. 1985. Culture and History in Medieval Iceland. An Anthropological Analysis of Structure and Change. Oxford:
Oxford University Press.

Herlihy, D. 1991. Family. The American Historical Review 96, $1-16$.

Jakobsson, Á. 2005. The specter of old age: nasty old men in the Sagas of Icelanders. Journal of English and Germanic Philology 104, 297-325.

Jakobsson, Á. 2008. The patriarch: myth and reality, pp. 26584 in Lewis-Simpson, S. (ed.), Youth and Age in the Medieval North. Leiden: Brill.

Jóhannesson, J. 1956. Íslendinga saga I. Pjóðveldisöld. Reykjavík: Almenna bókafélagið.

Jonsson, K. 2009. Practices for the Living and the Dead (Stockholm Studies in Archaeology 50). Stockholm: Stockholm University.

Karlsson, G. 2004. Goðamenning. Staða og áhrif goðorðsmanna i pjóðveldi Íslendinga. Reykjavík: Heimskringla.

Karlsson, G., Sveinsson, K. and Árnason, M. 1992. Grágás: lagasafn íslenska pjóðveldisins. Reykjavík: Mál og menning.

Kieffer-Olsen, J. 1993. Grav og gravskik i det middelalderlige Danmark - 8 kirkegårdsudgravninger. Unpublished PhD thesis, University of Aarhus.

Klevnäs, A. M. 2013. Whodunnit? Grave Robbery in Anglo-Saxon England and the Merovingian Kingdoms (BAR International Series 2582). Oxford: Archaeopress.

Kværness, G. 1996. Blote kan ein gjere om det berre skjer i løynd: kristenrettane $i$ Gulatingslova og Grágás og forholdet mellom dei (KULTs skriftserie nr 65). Oslo: Noregs forskingsråd.

Laslett, P. and Wall, R. (eds.) 1972. Household and Family in Past Times. Cambridge: Cambridge University Press.

Lee, C. 2008. Forever young: child burial in Anglo-Saxon England, pp. 17-36 in Lewis-Simpson, S. (ed.), Youth and Age in the Medieval North. Leiden: Brill.

Lewis, M. E. 2007. The Bioarchaeology of Children. Cambridge: Cambridge University Press.

Lewis-Simpson, S. (ed.) 2008. Youth and Age in the Medieval North. Leiden: Brill.

Lillehammer, G. 1989. A child is born. The child's world in an archaeological perspective. Norwegian Archaeological Review 22, 89-105.

Lynnerup, N. 1998. The Greenland Norse. A BiologicalAnthropological Study (Meddelelser om Grønland, Man \& Society 24). Copenhagen: The Commission for Scientific Research in Greenland.

Mays, S. A. 2000. Infanticide in earlier British populations, pp. 180-90 in Sofaer Deverenski, J. (ed.), Children and Material Culture. London: Routledge.

Mejsholm, L. 2009. Gränsland: Konstruktion av tidig barndom och begravningsritual vid tiden för kristnandet i Skandinavien. Unpublished PhD thesis, Uppsala University.

Miller, W. I. 1988. Some aspects of householding in the medieval Icelandic Commonwealth. Continuity and Change 3, 321-55.

Miller, W. I. 1990. Bloodtaking and Peacemaking: Feud, Law, and Society in Saga Iceland. Chicago: University of Chicago Press.

Mundal, E. 2005. Barn skal eigi lata dæya handa millim, pp. 1726 in Jakobsson, Á. and Tulinius, T. H. (eds.), Miðaldabörn. Reykjavík: Hugvísindastofnun Háskóla Îslands.

Murphy, E. and Le Roy, M. (eds.) 2017. Children, Death and Burial. Archaeological Discourses (SSCIP Monograph 5). Oxford: Oxbow Books.

Redfern, R. 2007. The influence of culture upon childhood: an osteological study of Iron Age and Romano-British Dorset, England, pp. 171-94 in Harlow, M. and Laurence, R. (eds.), 
Age and Ageing in the Roman Empire: Approaches to the Roman Life Course. Portsmouth: Journal of Roman Archaeology.

Sayer, D. 2010. Death and the family: developing generational chronologies. Journal of Social Archaeology 10, 59-91.

Sellevold, B. J. 1997. Children's skeletons and graves in Scandinavian archaeology, pp. 15-25 in De Boe, G. and Verhaeghe, F. (eds.), Death and Burial in Medieval Europe. Papers of the Medieval Europe Brugge 1997 Conference. Volume 2. Zellik: Institute for Archaeological Heritage.

Sellevold, B. J. 2001. From Death to Life in Medieval Hamar. Skeletons and Graves as Historical Source Material. Oslo: Unipub Forlag.

Sellevold, B. J. 2008. Child burials and children's status in medieval Norway, pp. 57-71 in Lewis-Simpson, S. (ed.), Youth and Age in the Medieval North. Leiden: Brill.

Shahar, S. 1997. Growing Old in the Middle Ages. 'Winter Clothes us in Shadow and Pain'. London: Taylor \& Francis.

Sigurðsson, J. V. 1999. Chieftains and Power in the Icelandic Commonwealth. Odense: Odense University Press.

Sigurðsson, J. V. 2000. Gårds- og kirkestruktur på Island fram til ca. 1200. Hikuin 27, 43-56.

Sigurðsson, J. V. 2008. Becoming 'old', ageisim and taking care of the elderly in Iceland c. 933-1300, pp. 227-42 in Lewis-Simpson, S. (ed.), Youth and Age in the Medieval North. Leiden: Brill.

Sofaer, J. R. 2006. The Body as Material Culture. A Theoretical Osteoarchaeology. Cambridge: Cambridge University Press.

Sofaer, J. R. 2011. Towards a social bioarchaeology of age, pp. 285-311 in Agarwal, S. C. and Glencross, B. A. (eds.), Social Bioarchaeology. Chichester: Wiley-Blackwell.

Steffensen, J. 1943. Knoglerne fra Skeljastaðir i Pjórsárdalur, pp. 227-60 in Stenberger, M. and Roussell, A. (eds.), Forntida gårdar i Island: meddelanden från den nordiska arkeologiska undersökningen i Island sommaren 1939. Copenhagen: Munksgaard.

Steffensen, J. 1975. Fólksfjöldi á Íslandi í aldanna rás, pp. 43449 in Steffensen, J. (ed.), Menning og Meinsemdir. Ritgerðarsafn um mótunarsögu íslenzkrar pjóðar og baráttu hennar við hungur og sóttir. Reykjavík: Ísafoldarprentsmiðja.

Welinder, S. 2001. The archaeology of old age. Current Swedish Archaeology 9, 163-79.

Zoëga, G. 2014. Early church organization of Skagaförður, North Iceland. The results of the Skagafjörður Church Project. Collegium Medievale 27, 23-62.

Zoëga, G. 2015. A family revisited: the medieval household cemetery of Keldudalur, North Iceland. Norwegian Archaeological Review 48, 105-28.

Zoëga, G. and Bolender, D. J. 2017. An archaeology of moments: Christian conversion and practice in a medieval household cemetery. Journal of Social Archaeology 17, 69-91.

Zoëga, G. and Murphy, K. 2016. Life on the edge of the arctic. The bioarchaeology of the Keldudalur cemetery in Skagafjörður, Iceland. International Journal of Osteoarchaeology 26, 574-84.

Pórarinsdóttir, B. 2005. Hirðin og hallærisplanið. Forgelgjur og unglingar í Eglu, pp. 113-36 in Jakobsson, Á. and Tulinius, T. (eds.), Miðaldabörn. Reykjavík: Hugvísindastofnun Háskóla Îslands.

Porgilsson, A. and Grønlie, S. 2006. Íslendingabók. Kristni saga. The Book of the Icelanders. The Story of the Conversion. London: Viking Society for Northern Research. University College London. 